\title{
1 A Lifelong Friendship
}

\subsection{Prague, 1882}

In September 1882, William James, the Assistant Professor of Philosophy at Harvard, took a sabbatical and sailed to Europe. James aimed at improving his acquaintance with the leading psychologists of his time and their ideas. He also had personal reasons to leave: his mother had died in January, and depression, restlessness and insomnia loomed as always. ${ }^{1}$ At the end of October, on his way from Venice to Dresden, James stopped in Prague, where he met the eminent physiologist Ewald Hering and the polyhedric physicist and philosopher Ernst Mach. James also paid a visit to Carl Stumpf, a young professor of philosophy who had come from Würzburg in $1879 .^{2}$ The name of his unannounced American guest probably did not ring any bell in Stumpf's mind. But James was one of the few Americans who had attentively read - and enjoyed - Stumpf's book of 1873 on the origin of the perception of space. ${ }^{3}$ I will leave a more detailed analysis of the issue of space to the next section of this Introduction; for now, let us say that Stumpf's nativistic and anti-idealistic views on the subject were highly congenial to James. During their days in Prague, James and Stumpf felt a reciprocal human sympathy that marked the beginning of a long and loyal friendship. Far beyond the mere obligations of academic courtesy, Stumpf was pleased to stroll around with the brilliant and somewhat unconventional American colleague. Stumpf's personality and his "more than hospitable reception" must have impressed James. Addressing his wife Alice the day after leaving Prague, he wrote:

With Stumpf I spent 5 hours on Monday evening, (This is Thursday) 3 on Wednesday morning, and 4 more in the afternoon, so I feel rather intimate. [. . .] He had another philosopher named Marty to dine with me yesterday, a jolly young fellow. [...] I learned a

1 See L. Simon, Genuine Reality. A Life of William James, New York, Harcourt Brace \& Co., 1998, p. 174, 182; R. Richardson, William James: in the Maelstrom of American Modernism. A Biography, Boston, Houghton Mifflin, 2006, p. 224.

2 H. Sprung, Carl Stumpf. Eine Biographie. Von der Philosophie zur experimentellen Psychologie, München-Wien, Profil, 2006, pp. 99-115. See also J. Hoskovec, “Carl Stumpf in Prag (1879-1884)”, Brentano-Studien 9, 2001, pp. 51-62.

3 C. Stumpf, Über den psychologischen Ursprung der Raumvorstellung, Leipzig, Hirzel, 1873. For an introduction to Stumpf's thought see D. Fisette, "Carl Stumpf”, in The Stanford Encyclopedia of Philosophy, ed. by E.N. Zalta, 2019; D. Fisette, “The Reception and Actuality of Carl Stumpf”, in Philosophy from an Empirical Standpoint. Essays on Carl Stumpf, ed. by D. Fisette and R. Martinelli, Amsterdam-Leiden-Boston, Brill-Rodopi, 2015, pp. 11-59.

https://doi.org/10.1515/9783110525533-001 
good many things from them, both in the way of theory and fact, and shall probably keep up a correspondence with Stumpf. ${ }^{4}$

On 26 November 1882, from Paris, James opened his first letter to his new friend in a direct and informal style:

My Dear Stumpf, I'm sure you will allow me to drop titles of ceremony with a colleague with whose person and whose ideas alike I feel so warm a sympathy; \& I trust that when you write to me you will give the same token that you regard me in the light of an old friend. ${ }^{5}$

Stumpf gladly agreed:

Dear James! I likewise return your greetings with sincere joy, for I have gained with your all-too-brief visit the firm impression that we not only harmonize in our scientific views and intentions in a rare way, but will also always be good friends. ${ }^{6}$

James and Stumpf kept up their correspondence for 28 years, until James's death in 1910. The year 1882, Stumpf writes in his Autobiography of 1924, "brought to us our great joy, a visit from William James, [...] with whom I soon found myself on terms of friendship". 7 In 1927, 17 years after his friend's death, Stumpf wrote for Kant-Studien an essay on James's thought and personality, with reference to the first edition of his correspondence. ${ }^{8}$

Born in Wiesentheid in 1848, the young Carl Stumpf was introduced to philosophy by his acquaintance with Brentano in Würzburg. Like many others,

4 [58, 1882]. Together with Stumpf, Anton Marty (1847-1914) belongs to the first generation of Brentano's pupils. Leaving Prague in 1885, Stumpf wrote: "I [. . . ] parted with my dear friend Marty with pain; I will never again find such a trusted and at the same time scientifically stimulating companion” [6, 1885]. In 1892 Marty reviewed James's Principles of Psychology: see [19, 1892]. On Marty's thought see Mind and Language. On the Philosophy of Anton Marty, ed. by G. Fréchette and H. Taieb, Berlin, de Gruyter, 2017; L. Cesalli, “Stumpf's (Early) Insights and Marty’s Way to His (Later) Sprachphilosophie”, in Essays on Stumpf, pp. 359-384.

$5[1,1882]$.

$6[2,1882]$.

7 "The year 1882 brought to us our great joy, a visit from William James, who had liked my book on space, and with whom I soon found myself on terms of friendship. Later we met again in Munich and we kept up our correspondence to the end, though I could not follow him in his conversion to pragmatism”. Stumpf, Autobiography, p. 399.

8 C. Stumpf, "William James nach seinen Briefen. Leben. Charakter. Lehre”, Kant-Studien 32, 1927, pp. 205-241; also Berlin, Pan Verlag, 1928. Reprinted in the Appendix III to this volume. Besides his personal memories, Stumpf quotes from The Letters of William James, Boston, Little \& Brown, 1920. See below, in this Introduction. 
Stumpf had been deeply impressed by Brentano's rigorous style of thinking, his sharp-mindedness and logical rigor. ${ }^{9}$ Following his mentor's advice, Stumpf went to Göttingen to attend Hermann Lotze's lectures. ${ }^{10}$ In the wake of Brentano, who was a Catholic priest, Stumpf entered seminary in 1869. However, the proclamation of the infallibility of the Pope in 1870 caused a deep religious crisis in Brentano and Stumpf, both of whom eventually took off the black robe. Not yet ordained, Stumpf faced less serious consequences than his mentor. In 1873, at the age of 25, Stumpf became Full Professor and succeeded to Brentano in Würzburg. ${ }^{11}$ That was the beginning of a long and successful career for Stumpf, who subsequently taught in Prague, Halle, Munich and Berlin.

William James' education had been less linear. The son of Henry James Sr., a moralist and theologian who was friends with Ralph Waldo Emerson and was influenced by Swedenborg and Fourier, ${ }^{12}$ William lived in a cultivated and cosmopolitan milieu. Born in New York in 1842, he grew up “zig-zagging” between Newport, Boston and long European sojourns, during which he learned good French and German. ${ }^{13}$ At the age of 22, James entered the medical school at Harvard, where he would start teaching in 1872. James's health was repeatedly challenged by high peaks of depression. In 1870 he went through a severe

9 "Towards the end of this semester came the great change, by the addition of Franz Brentano to the faculty. Elsewhere I have already described the complete change which this man's appearance, his personality, his manner of thinking and teaching wrought in me. Everything else vanished before the great problems of philosophical and religious regeneration". Stumpf, Autobiography, pp. 391-392. The reference here ("elsewhere ...") is to C. Stumpf, "Erinnerungen an Franz Brentano", in Franz Brentano. Zur Kenntnis seines Lebens und seiner Lehre, ed. by O. Kraus, München, Beck, 1919, pp. 87-149. On the relations between Brentano and Stumpf see K. Schuhmann, “Carl Stumpf (1848-1936)”, in The School of Franz Brentano, ed. by L. Albertazzi et al., Dordrecht, Kluwer, 1996, pp. 109-129.

10 On the importance of Lotze for Stumpf's intellectual development, see N. Milkov, "Carl Stumpf's Debt to Hermann Lotze”, in Essays on Stumpf, pp. 101-122.

11 Sprung, Carl Stumpf. Eine Biographie, cit., p. 75. On Stumpf's youth see W. Baumgartner, “The Young Carl Stumpf. His Spiritual, Intellectual, and Professional Development”, in Essays on Stumpf, pp. 61-74.

12 See R.B. Perry, The Thought and Character of William James, as Revealed in Unpublished Correspondence and Notes, Together with his Published Writings, 2 vols., London, Humphrey Milford, Oxford University Press, 1935, p. 20 ff.

13 Richardson coined for William James the fortunate phrase "growing up zigzag" (Richardson, William James: in the Maelstrom of American Modernism, p. 17); see also J. Carrette, "Growing up Zig-Zag: reassessing the transatlantic legacy of William James", in William James and the Transatlantic Conversation. Pragmatism, Pluralism, and Philosophy of Religion, ed. by M. Halliwell and J.D.S. Rasmussen, Oxford, Oxford University Press, 2014, pp. 199-217. See also Simon, Genuine Reality, cit., pp. 44-45. 
crisis, which he overcame after reading a philosophical essay by Charles Renouvier. James famously wrote in his Diary:

I think that yesterday was a crisis in my life. I finished the first part of Renouvier's 2nd Essay and saw no reason why his definition of free will - the sustaining of a thought because I choose to when I might have other thoughts - need to be the definition of an illusion. At any rate, I will assume for the present - until next year - that it is no illusion. My first act of free will shall be to believe in free will. ${ }^{14}$

By the time of their Prague meeting, in 1882, the main achievements and works of the two friends were still inchoate: Stumpf's Tonpsychologie appeared in two volumes in 1883 and 1890; James released the Principles of Psychology in 1890. The year 1890, then, marks a turning point in the intellectual biographies of both thinkers. The general consensus is that after the publication of the Principles of Psychology, James progressively abandoned psychology and became more and more involved in philosophy. ${ }^{15}$ Though he dropped all experimental activities, however, James was far from abruptly dismissing psychology as a whole. Rather, he began to focus on the metaphysical side of the same problems he had investigated psychologically: his correspondence with Stumpf stands among the clearest documents of this evolution. ${ }^{16}$ Somewhat less spectacularly, the year 1890 also

14 Quoted from Perry, Thought and Character 1, p. 323; see also Richardson, William James: in the Maelstrom of American Modernism, cit., p. 120; B. Kucklick, The Rise of American Philosophy. Cambridge, Massachusetts, 1860-1930, New Haven-London, Yale University Press, 1977, p. 161 ff. Dunham notes: "James's colourful announcement of his conversion to a belief in free will, which he credits to reading Renouvier's Traite de psychologie rationnelle, is frequently cited in histories of his thought and pragmatism more generally. Beyond this, however, little has been written in English on Renouvier's philosophy". J. Dunham, "Idealism, Pragmatism and the Will to Believe: Charles Renouvier and William James", British Journal for the History of Philosophy 23, 2015, p. 756.

15 The year 1890 marks "the midpoint in James's creative life”. J. Barzun, A Stroll with William James, Chicago and London, The University of Chicago Press, 1983, p. 7. However, any attempt to distinguish subsequent "phases" in his work is an oversimplification. "It is sometimes said that James began as a physiologist and ended as a religious mystic, having passed successively through psychology, epistemology, and metaphysics on the way. There is some justification of this view in his formal schooling and in the chronological sequence of his teaching and writing. [...] As a matter of fact James's scientific and religious interests were equally early and equally enduring" [Thought and Character 1, p. 449].

16 "Letters to Stumpf afford a clear view both of James's varied activities during the decade of the '90s, and of the persistence of his psychological interests despite a growing preoccupation with philosophy" [Thought and Character 2, pp. 179-180]. In 1875 James had straightforwardly affirmed that psychology is "of course the antechamber to metaphysics". W. James, "Review of Wundt, Grundzüge der physiologischen Psychologie (1875)”, North American Review 121, 1875, p. 195 [Works 17, p. 296]. 
marked a change in Stumpf's activity. Leaving Tonpsychologie unfinished with the second volume, Stumpf turned to a multiplicity of different projects, both in philosophy and psychology. Berlin was the ideal place for the development of his multi-faceted - albeit highly dispersive - activities. ${ }^{17}$

This parallel intellectual development was mirrored in the correspondence between the two thinkers. James repeatedly voiced his intention to focus on the ultimate questions of metaphysics and morals. In 1899 he went so far as to express to Stumpf his "horror” for experimentation:

I fear I am ceasing to be a psychologist and becoming exclusively a moralist \& metaphysician. I have surrendered all psychological teaching to Munsterberg [sic] and his assistant, and the thought of psychophysical experimentation, and altogether of brass-instrument and algebraic-formula psychology fills me with horror. ${ }^{18}$

Stumpf's reaction was quite interesting. Manifesting his agreement with James as to the importance of metaphysics, in 1886 he vowed to abandon experimentation on sounds and to "lay to rest the tone psychology project, in order to bring to fruition so much else that lies in my heart and my mind". ${ }^{19}$ A glance at Stumpf's publications shows that he failed to achieve this goal. ${ }^{20}$ Stumpf delayed the second volume of Tonpsychologie for four more years, and the planned third volume was eventually cancelled. It was only after his retirement in the early 1920s that Stumpf could concentrate upon philosophy. Yet he never saw the publication of his monumental Erkenntnislehre ${ }^{21}$ in two volumes: the book was posthumously edited by his son Felix in 1939-1940 - that is, when its

17 On his intense Berlin years, Stumpf wrote: "I have been able to pursue every kind of work, often fully, in every direction that interested me. Berlin's genius loci, the all-pervading spirit of work, had caught me. Inspirations came a-plenty, and there was no question, however remote, on which one could not find an expert opinion. Berlin was, moreover, musically the foremost city of the world, and Joachim, that noblest of performing artists whom I had known for some time as a friend, was still in his prime. All the great men with whom, during these many years, I came into closer touch officially, personally, and often socially, I cannot even name here". Autobiography, p. 402.

18 [35, 1899]. Concerning Münsterberg, see below.

19 [8, 1886]. In 1924, Stumpf retrospectively avowed: "I never intended to spend so much of my lifetime on acoustics and musical psychological studies as I did later on. I had counted on a few years. But it was, after all, not musical science but philosophy that always remained mistress of the house, who, it is true, granted most generously great privileges to her helpmate”. Autobiography, pp. 396-397.

20 See D. Fisette, "Bibliography of the Publications of Carl Stumpf. Bibliographie der Schriften von Carl Stumpf”, in Essays on Stumpf, pp. 529-541.

21 C. Stumpf, Erkenntnislehre, 2 vols., ed. by F. Stumpf, Leipzig, Barth, 1939-1940. 
reception in Germany was highly unfavoured. ${ }^{22}$ Along with other writings, his correspondence with James is an important document of Stumpf's views on philosophy and of his permanent commitment to it. ${ }^{23}$

\subsection{The U.S. and Germany}

Besides its scientific value, the correspondence between Stumpf and James testifies to a human relationship and, at the same time, to an entire epoch. ${ }^{24}$ Comments on friendship and loyalty play a certain role within the exchange. Quite early, the two correspondents agreed to "hear of each other at least once a year", ${ }^{25}$ but that was not always the case. When James wrote his "annual" letter on the 1st of January 1904, he hadn't heard from Stumpf in three years. ${ }^{26}$ Previously, it had been Stumpf's turn to complain about James's alleged coldness and distraction during the long-awaited second - and last - meeting of 1893. ${ }^{27}$

22 Stumpf's late writings have been often neglected by scholars. Among the few studies on his Erkenntnislehre see R. Rollinger, "The Concept of Causality in Stumpf's Epistemology”, in Austrian Phenomenology: Brentano, Husserl, and Meinong on Mind and Object. Frankfurt a.M., Ontos, 2008, pp. 263-300; R. Martinelli, "Stumpf on Categories", in Essays on Stumpf, pp. 203-227.

23 Despite his activity as a psychologist, Stumpf never abandoned philosophy and permanently considered himself a philosopher. See G.M. Ash, Gestalt Psychology in German Culture, 1890-1967. Holism and the Quest for Objectivity, Cambridge, Cambridge University Press, 1995, p. 30. This book gives a resourceful picture of the development of Gestalt psychology at the Berlin Institute directed by Stumpf. Among the interpreters who wrongly assume that Stumpf abandoned philosophy in favor of experimental psychology see e.g. Sprung, Carl Stumpf. Eine Biographie, cit., p. 15.

24 "The life of William James was widely spread, both in its roots and in its branches. It took its nourishment from many sources, grew in many directions, and bore a great variety of fruits. It was richly fertilized and abundantly fertile. Having a peculiar genius for friendship, James entered into relations of intimacy with a large circle of contemporaries [...]. Habits of travel and a knowledge of languages widened the scope of his sociability, and made him an important channel by which America was carried to Europe and Europe to America. In short, his life and mind were so interwoven with their context, so thoroughly socialized and humanized, that a record of them must necessarily be in some measure a history of his epoch" [Thought and Character 1, p. ix].

25 [2, 1882].

26 "I feel that, if I let the year 1904 begin without anything in the way an electric current passing, the way from your heart to mine is in danger of becoming obliterated by the growth of distance and time" [50, 1904].

27 [23, 1893]. 
James and Stumpf sometimes spoke of a common spiritual root lying below the surface of character traits, unshaken by the undeniable differences of personality, and the (increasing) theoretical ones between them. ${ }^{28}$ Despite all divergences, however, they somehow complemented each other. James considered Stumpf a model of moral righteousness, zeal in research and style as a writer. He praised Stumpf's writings for “exhaustive thoroughness, subtlety of discrimination, firmness and clearness of style, and incorruptible good sense", ${ }^{29}$ he spoke of a "roman severity of style" which makes Stumpf's works "very impressive - monumental, as it were". 30

As Stumpf noted in his essay of 1927, James's peculiar eagerness to give eulogies of people around him must be considered here. ${ }^{31}$ But his appreciation of Stumpf's public and private writings goes beyond that. To some extent, it should be interpreted in terms of national characters. In his letters, indeed, James frequently touches upon Germany and the U.S., with interesting comparisons, appreciations and occasional criticism. Remarkably, and not by chance, some of James's most quoted pronouncements on America and “Americanism” are drawn from his correspondence with Stumpf. ${ }^{32}$ In James’s eyes, Stumpf championed a

28 James wrote: "It is a strange fact - for your positive and constructive ideas seem to have no great similarity to mine - that I feel you, perhaps more than any other psychologist whom I read to day, to be a gleichgesinnter Mensch with myself. I am sure that if fate had allowed us to grow side by side we could have worked out many things together - a thing now probably impossible even if we were side by side, on account of the difficulties which increasing age brings to the irresponsible interchange of unmatured ideas" [17, 1891].

29 [5, 1884].

$30[40,1900]$.

31 Stumpf, William James, p. 221. From a methodological point of view, James's enthusiasm must be taken into account by scholars who don't want to be misled by his oratorical ability in endorsing different philosophical theses. See R. Gale, The Divided Self of William James, Cambridge, Cambridge University Press, 1999, p. 20. However, Gale's thesis of the "divided self" - i.e. the coexistence of a Promethean and a mystic self within James - is too rigid a hermeneutic criterion. J. Pawelsky, The Dynamic Individualism of William James, Albany, SUNY Press, 2007, suggests that James "made real progress toward integrating his two selves" (p. 108). His correspondence with Stumpf shows the he actually did. In turn, Pawelsky overrates the role of the "reflex arch" in James's psychology. Against Gale's thesis see also W. Cooper, The Unity of William James's Thought, Nashville, Vanderbilt University Press, 2002, p. 34 and passim. See also M. Gale, "The Still Divided Self of William James: A Response to Pawelski and Cooper”, Transactions of the Charles S. Peirce Society 60, 2004, pp. 153-170.

32 "It unsettles my americanism (that tender plant) to go too often abroad [...] It is no light matter to feel foreign in one's native land. I am just beginning to feel american again, when this temptation comes!” [29, 1895]. In response to Stumpf's remarks [30, 1896], James added a lesser famed statement: "My fear of losing my Americanism if I went abroad again was entirely complimentary to your side of the Atlantic. Civilization is so much more advanced in many 
set of virtues which were not merely individual, but epitomized the good qualities of the German people. ${ }^{33}$

Some excerpts from the correspondence may illustrate this point. In 1882, James wrote to Alice: "With the nourishing breath of the german air, and the sort of smoky and leathery German smell, vigor and good spirits have set in. I've walked well, \& slept well \& eaten well and read well, and in short begin to feel as I expected I should when I decided upon this arduous pilgrimage". ${ }^{34}$ Positively commenting on the first volume of Stumpf's Tonpsychologie, James wrote: "[y]our German brains are built after another fashion from those of the rest of us, you can carry a heavier freight of facts, \& handle them in a freer way". ${ }^{35}$ To be sure, even the solid German cast of mind has some drawbacks. At times, especially in his later writings, James ironically voiced his distance from the German "professorial" style. ${ }^{36}$ To the severe Gründlichkeit instilled into German philosophy by Christian

ways with you, and the American so quickly catches the European tone, that when he comes back he finds his own country in many ways foreign and displeasing, and it takes him a long time to resume his old, simple minded relations with it. I have suffered from this discord many times, particularly after my last return home; I am now on thoroughly good terms with my native land, and dread very much to throw myself out of tune again. Like all ideal things, harmony of this kind must be worked for and bought by certain renunciations. We have many ideal things here, and the best thing an American can do is to stay at home as much as possible, and try to increase them" [31, 1896].

33 The "ever-alluring theme of Germanic traits" [Thought and Character, 1, p. 280] recurs frequently in James's early correspondence, especially during his time abroad.

34 [58, 1882]. During his previous stay of 1867, from Berlin, James wrote to Edmund Tweedy: "if I had to be born a 'foreign' child at all, I don't know that I could do a more comfortable thing than have it done in Germany. The ways of living are (as a whole) so sensible and easy, there seems to be such a good, fat, homely atmosphere about the inner family life of the people, as well as about much of their public life, that a German child's early associations must have an uncommon richness and stoutness, so-to speak, even if they have not much artistic elevation. Then as a boy and youth you can certainly get the best education in the world. Perhaps, after all, it is a better place to grow up in than to live in after you have grown up. The people are a swarming set, and without ever seeming to be in a hurry, get through a great deal of work" [Corr. 4, p. 241].

$35[5,1884]$.

36 "In a subject like philosophy it is really fatal to lose connexion with the open air of human nature, and to think in terms of shop-tradition only. In Germany the forms are so professionalized that anybody who has gained a teaching chair and written a book, however distorted and eccentric, has the legal right to figure forever in the history of the subject like a fly in amber. All later comers have the duty of quoting him and measuring their opinions with his opinion. Such are the rules of the professorial game - they think and write from each other and for each other and at each other exclusively [...] and if by chance any one writes popularly and about results only, with his mind directly focused on the subject, it is reckoned oberflächliches zeug and ganz unwissenschaftlich". W. James, A Pluralistic Universe. Hibbert Lectures at Manchester 
Wolff - as already Kant put $\mathrm{it}^{37}$ - James opposed a more direct and "popular" style, representative of a quintessentially American "entrepreneurial" spirit. ${ }^{38}$ However, James largely identified the typical "German professor" with Wundt, rather than with Stumpf. ${ }^{39}$

Applauding Stumpf's "solidity of heartiness", ${ }^{40}$ James explained: "it is partly deutsch, but not all the Deutschen have it; so I make the most of it. Besides, so far off, you are the ideal homo or vir, and when you speak kindly, as now of my book, it is as if I were being approved by 'the Absolute', an Absolute moreover who can write a Tonpsychologie!" 41 Needless to say, reference to the Absolute in this context adds a benign and intimately ironic touch. In sum, James swayed between a sincere admiration for Europe ${ }^{42}$ on the one side, and the urge to cultivate his profound feelings towards America on the other. ${ }^{43}$ Less interested in such themes, Stumpf contented himself with some comparisons between the educational systems of the two countries. ${ }^{44}$ Significantly, however, he closed his 1927 essay on James ${ }^{45}$ with the opening lines of Goethe's famous poem "The United States".

\footnotetext{
America, you are better off

Than our ancient continent.

You have no tumbledown castles

And no basalt deposits.
}

College on the Present Situation in Philosophy, New York and London, Longmans, Green \& Co., 1909, pp. 17-18 [Works 4, p. 13].

37 Wolff is referred to as "the author of a spirit of well-groundedness in Germany that is still not extinguished": I. Kant, Critique of Pure Reason, ed. by P. Guyer and A. Wood, The Cambridge Edition of the Works of Immanuel Kant, vol. 2, Cambridge, Cambridge University Press, 1998, p. 120 (B 36).

38 For a contextual discussion, see H. Paul, "German Thoroughness in Baltimore: Epistemic Virtues and National Stereotypes”, History of Humanities 3, 2018, pp. 327-350.

$39[10,1887]$. See below in this Introduction.

$40[14,1890]$.

$41[14,1890]$.

42 Especially German civilization and the Swiss landscape: see [22, 1893].

43 "He found work a cure for too much play, and play a cure for work; nature a cure for social fatigue, and civilization a cure for the emptiness of primitive nature; philosophy a cure for science and science for philosophy; he went to Europe when he suffered from America, and sought in America a cure for Europe" [Thought and Character 1, p. 234].

44 [4, 1884].

45 Stumpf, William James, p. 241. Besides rendering homage to James, with this quote Stumpf made fun of Ernst von Aster's Introduction to the German translation of James's Human Immortality: W. James, Unsterblichkeit, trans. by E. von Aster-Giessen, Berlin, Philo-Verlag, 1926. 
Your inner lives are not disturbed by

Useless memories and vain strife. ${ }^{46}$

In all this, the reader of the correspondence should obviously keep in mind the peculiar state of transatlantic relations in the late nineteenth century, when Germany was leading the way in scientific research. American students with career ambitions regularly sailed for Germany to assimilate concepts and methods from state-of-the-art psychological laboratories. Occasionally, James also recommended American pupils or researchers to Stumpf's benevolence. ${ }^{47}$ The opposite shore of the Atlantic Ocean was not as attractive at the time. Though he accepted a position at Harvard, for instance, Hugo Münsterberg strove to go back to Germany for a long time. ${ }^{48}$ Münsterberg was in charge for experimental activities at Harvard, to James's great relief: "I may say that I myself enjoy inward peace and a good professorial conscience for the first time, now that Münsterberg has taken charge of the entire experimental field". ${ }^{49}$

46 "Amerika, du hast es besser / Als unser Kontinent, das alte, / Hast keine verfallne Schlösser / Und keine Basalte. / Dich stört nicht im Innern / Zu lebendiger Zeit / Unnützes Erinnern / Und vergeblicher Streit”. J.W. Goethe, "Den vereinigten Staaten”, from Zahme Xenien, 1827. J.W. Goethe, Sämtliche Werke, Briefe, Tagebücher und Gespräche, Sect. 1, vol. 2: Gedichte 1800-1832, Frankfurt a.M., Suhrkamp, 1988.

47 Arthur H. Pierce [27, 1894]; George M. Stratton [28, 1895]; Mary W. Calkins [49, 1902]. For Pierce's negative feedback concerning Stumpf's lab in Berlin, see the footnotes to [27, 1894] and $[28,1895]$.

48 "Although Münsterberg first came to Harvard in 1892 as a visiting professor, it would not be until 1897 that he accepted a permanent position. During the early and middle 1890s James courted him as his replacement in the Harvard Psychological Laboratory. [...] Hugo wanted a prestigious position in a German university. In experimental psychology that meant either Leipzig or Göttingen. And unfortunately for his prospects he had criticized both Wundt and Göttingen's laboratory experimentalist, Georg Elias Müller. Moreover, there was little indication that being a Jew enhanced prospects for professional advancement”. D.W. Bjork, The Compromised Scientist: William James in the Development of American Psychology, New York, Columbia University Press, 1983, p. 45. On 7 March 1892, accepting James’s invitation, Münsterberg wrote: "Under no circumstance would I stay more than three years in America. I want to remain a German, and I consider the whole thing merely as a big beautiful instructive travel” [Corr. 7, p. 246].

49 [26, 1894]. On Münsterberg's calling to Harvard see [19, 1892]. The decision eventually proved to be a bad one: "Münsterbergian anecdotes abounded. All alluded to his German background or academic elitism, which often were conflated"; later, "the anecdotes ceased to be amusing tales about a blustering foreigner and became woven into the suspicion that he was a subversive. Münsterberg's unceasing attempts to promote a German-American scholastic alliance, his intercession into delicate early twentieth century diplomacy between the United States and Germany, and finally the hysteria of World War I changed him from a caricature into an enemy. [...] Fortunately James did not live long enough to see Münsterberg's tragic failure”. Bjork, The Compromised Scientist, cit., pp. 54-55. 
This historical situation influenced German institutions and, indirectly, Stumpf's career. For the most part, American students headed to Leipzig, where Wundt had established a renowned experimental laboratory in 1879. No wonder that the Berlin Friedrich-Wilhelm Universität determined to challenge this primacy by establishing a prestigious Institute of Psychology in the capital. Following the influential advice of Wilhelm Dilthey, who sought a man with both experimental skills and robust philosophical training, the direction was offered to Stumpf, who was in Munich at the time. ${ }^{50}$ After some hesitation and against Brentano's opinion, ${ }^{51}$ in 1894 Stumpf finally accepted. His move to Berlin was frequently discussed in the correspondence: James insisted that the "helmeted" manners of the Prussian would eventually overwhelm his friend. ${ }^{52}$ All in all, he was right. After some resistance, Stumpf eventually conceded that James had a point in disapproving of the frenetic lifestyle of the tentacular capital. ${ }^{53}$ However, in 1924 he retrospectively noted that "after thirty years, I still believe that my decision was for the best". ${ }^{54}$ As for James, even the relatively smaller dimension of the American college eventually proved too demanding: in 1907 he resigned from Harvard to exclusively devote himself to research. ${ }^{55}$

\subsection{Public and Private Life}

Along with letters and postcards, James and Stumpf regularly sent to each other their most representative publications. Commentaries and criticisms on these works make up the most significant part of the correspondence from a

50 On the circumstances around Stumpf's calling to Berlin see Ash, Gestalt Psychology, pp. 31-35. See also Sprung, Carl Stumpf. Eine Biographie, cit., p. 124 ff.; V. Gerhart, R. Mehring, J. Rindert, Berliner Geist. Eine Geschichte der Berliner Universitätsphilosophie bis 1946, Berlin, AkademieVerlag, 1999, p. 168.

51 See a letter to Stumpf dated 8 September 1893, in F. Brentano, Briefe an Carl Stumpf 1867-1917, ed. by G. Oberkofler, Graz, Akademische Druck-und Verlagsanstalt, 1989, p. 100.

52 "I only feared that Berlin might prove a rasping, fatiguing, and ungemüthlich place to live in, and that you might be buying honour, if you accepted the appointment, at the price of peace of soul". [26, 1894]; "I am always overworked, and I hope that on your part Berlin is not proving too terrible a taskmistress”. [28, 1895]. See also [29, 1895]; [31, 1896]; [33, 1899]; [50, 1904]; [54, 1907].

53 [51, 1904].

54 Autobiography, p. 402.

$55[54,1907]$. 
scientific point of view. Unsurprisingly, the widest epistolary discussions concern the correspondents' major works: Stumpf's Tonpsychologie vols. 1 and 2 (1893, 1890) and James's Principles of Psychology (1890) and Varieties of Religious Experience (1902). ${ }^{56}$ In addition to their own, James and Stumpf also discussed the works and ideas of others: leading scientists and philosophers of the time recur in the correspondence along with names now forgotten. The footnotes added to the letters provide a reasonably detailed account concerning both categories. In this Introduction, attention will be paid exclusively to three outstanding authors: Wundt, Mach, and Brentano.

Wilhelm Wundt is by far the most quoted scientist in the correspondence. James had a somewhat ambivalent attitude towards him. His first meeting with Wundt in 1882 left James with a positive impression of the man. ${ }^{57}$ At the time, James and Stumpf frequently targeted Wundt's early theories. They attacked with particular insistence the "relativity of sensations" and the hypothesis of Innervationsgefühle. ${ }^{58}$ However, James later softened his tones against Wundt: he did maintain a critical attitude, yet he tried to do justice to Wundt's respectability more than Stumpf expected him to do. In James's eyes, Wundt represented the quintessential "German professor", halfway between Wolff's scholastic encyclopedism and Napoleon's bravery in tackling a multiplicity of enemies at once. ${ }^{59}$ Indeed, in James's view, Wundt's work was fragmentary, it had no core: "[c]ut him up like a worm, and each fragment crawls; there is no noeud vital in his mental medulla oblongata, so that you can't kill him all at once". ${ }^{60}$ Interestingly, in a letter to Alice of 18 November 1882, James directly contrasts the impressions made upon him by Wundt and Stumpf:

56 C. Stumpf, Tonpsychologie, vol. 1, Leipzig, Hirzel, 1883; Tonpsychologie; vol. 2. Leipzig, Hirzel, 1890. W. James, The Principles of Psychology, New York, Holt, 1890; W. James, The Varieties of Religious Experience. A study in Human Nature, being the Gifford Lectures on Natural Religion delivered at Edinburgh in 1901-1902, New York, London and Bombay, Longmans, Green and Co., 1902.

57 "Wundt in Leipzig impressed me very agreeably personally. He has a ready smile and is entirely unaffected and unpretending in his manner. I heard him twice, and was twice in his laboratory, he was very polite but showed no desire for a further acquaintance" $[1,1882]$. Suggesting that James had no previous acquaintance with him, this formulation is consistent with Horst Gundlach's claim that James did not pay visit to Wundt in Heidelberg in 1867. H. Gundlach, "William James and the Heidelberg Fiasco", History of Psychology 21, 2018, pp. 47-72.

58 [2, 1882], [5, 1884], [8, 1886]. See below, ch. 2 of this Introduction.

59 [10, 1887], [24, 1893].

60 [10, 1887]. For a commentary, see S. Araujo de Freitas, Wundt and the Philosophical Foundations of Psychology. A Reappraisal, Cham, Springer, 2016, p. 18. 
[Wundt] made a very pleasant and personal impression on me, with his agreeable voice and ready, tooth-showing smile. His lecture also was very able, and my opinion of him is higher than before seeing him is. But he seemed very busy and showed no desire to see more of me than the present interview either time. The psychologische Gesellschaft I stayed over to see was postponed, but he did not propose to me to do anything else - to the gain of my ease, but to the loss of my vanity. Dear old Stumpf has been the friendliest of these fellows. With him I shall correspond. ${ }^{61}$

Stumpf's opinion on Wundt was definitely less indulgent. He considered Wundt little else than a charlatan who misled more than a generation of researchers. ${ }^{62}$ Stumpf and Wundt stayed on indirectly hostile terms for a long time: for example, Wundt's "completely perfidious" review of Stumpf's Tonpsychologie appeared as anonymous. ${ }^{63}$ Crossing swords became unavoidable when Stumpf harshly criticized the work of Carl Lorenz, a pupil of Wundt who, so to speak, invaded Stumpf's field by investigating the psychological foundations of musical consonance. ${ }^{64}$ The polemic between Wundt and Stumpf soon reached a "dangerous stage", to use James's effective expression. ${ }^{65}$ Diverging opinions about Wundt occasioned some misunderstandings between James and Stumpf. For example, after a long criticism of Wundt in a letter of 1886, Stumpf was afraid of having crossed the line, annoying James with his "demeanor" against the Leipzig psychologist. ${ }^{66}$ Reassuring his friend, though, James proved the concern completely misplaced. ${ }^{67}$

61 Corr. 5, p. 301.

62 "He makes students and others believe that the ever repeated measurements of reaction times inaugurates a completely new 'experimental psychology', which can only look back at older psychology with derision and scorn. [...] As if something important were to follow from time measurements, as if they did not have to be interpreted themselves only through inner observation, and finally as if numbers and not, rather, clear concepts were the main point!" $[8,1886]$.

63 See Sprung, Carl Stumpf. Eine Biographie, cit., pp. 109-111, and [6, 1885].

64 Following Wundt's methodology of "intermediate graduation" (mittlere Abstufung) Lorenz determined that the fifth is the (psychologically) intermediate sound within an octave. Owing to this peculiar position, Lorenz concluded, the fifth is consonant. Stumpf objects that - on the contrary - the fifth tends to emerge in Lorenz's experiments of intermediate graduation because it is a consonant interval. For all references, see the footnotes added to $[13,1890]$ and $[17,1891]$.

$65[17,1891]$.

66 [23, 1893]. In his obituary of Stumpf, Kurt Lewin recalls that Wundt's name "was nearly taboo in the Berlin Institute”. K. Lewin, "Carl Stumpf”, The Psychological Review 44, 1937, p. 194.

67 [24, 1893]. 
Another interesting case is that of Ernst Mach. Mach believed that the basic elements of the world - he called them "sensations" - become part either of the physical or of the mental world as soon as they aggregate with other elements. ${ }^{68}$ Stumpf was definitely skeptical of this view, which he considered a philosophically unsophisticated and ultimately untenable pseudo-explanation. ${ }^{69}$ As a case in point, Stumpf's opening address at the third Congress of Psychology, held in Munich in 1896 under his presidency, was devoted to a ruthless criticism of Mach's principle of psycho-physical parallelism. ${ }^{70}$ Remarkably, at the time James

68 "On a bright summer day under the open heaven, the world with my ego suddenly appeared to me as one coherent mass of sensations, only more strongly coherent in the ego. Although the actual working out of this thought did not occur until a later period, yet this moment was decisive for my whole view”. E. Mach, Beiträge zur Analyse der Empfindungen, 1886; Eng. trans. Contributions to the Analysis of the Sensations, Chicago, Open Court, 1897, p. 23. In his interesting foreword to this English edition, Mach wrote: "I am of opinion [...] that the idea advanced in the present work, agreeably to which as many physico-chemical neural processes are to be assumed as there are distinguishable qualities of sensation, is [...] possessed of heuristic value, and that there is reasonable hope that at some future time it, too, will receive elucidation from the side of physiological chemistry. Admittedly, this idea [...] is but a consistent, monistic conception of Muller's principle of the specific energies [...]. (p. v).

69 "Mach's text was a cause of much enjoyment for me; but if one looks more closely at it, much of it dissolves into Aperçu's writings, which are more witty than true” [8, 1886]. Stumpf reviewed Mach's book both in the 1886 edition and in the subsequent augmented one, published under the title Die Analyse der Empfindungen. See [8, 1886] and the relative footnotes.

70 C. Stumpf, "Eröffnungsrede des Präsidenten, Prof. Dr. Carl Stumpf”, in Dritter International Congress für Psychologie in München vom 4-7 August 1896, München, Lehmann, 1897, pp. 3-16. Published with some modifications as "Leib und Seele" in C. Stumpf, Philosophische Reden und Vorträge, Leipzig, Barth, 1910, pp. 65-93. For contingent reasons, Mach reacted late to Stumpf's speech. E. Mach, "Sinnliche Elemente und naturwissenschaftliche Begriffe", Pflügers Archiv für die gesamte Physiologie des Menschen und der Tiere, 136, 1910, pp. 263-274. He writes: "At the opening of the International Congress for Psychology in Munich, a meeting held on August 4, 1896, Prof. Dr. Carl Stumpf gave an address in which he also undertook to criticize my epistemological views in psychology. I was indeed inscribed as a participant of the Congress, but because of its strongly hypnotic-telepathic program did not attend. Since I was then occupied with other things and just afterwards stricken by serious illness, Stumpf's speech came to my attention late. In a series of editions of Analyse der Empfindungen, I have indeed answered the objections of Carl Stumpf and others, which I view neither as personal nor malicious, but typical, but since Stumpf's talk has recently gone into a third edition, I want to add here a comparison between my representation and the main passages of his speech in so far as they relate to me". Quoted from the English translation: E. Mach, "Sensory Elements and Scientific Concepts" in Ernst Mach. A Deeper Look. Documents and New Perspectives, ed. by J.T. Blackmore, Dordrecht, Kluwer, 1992, pp. 125-126. 
commented positively on Stumpf's address. ${ }^{71}$ Ten years after Mach's Beiträge, then, James was far from sharing Mach's positions without reservations, let alone defending them against Stumpf's uncharitable attack. Still, James had a different attitude toward the Viennese scientist. He highly esteemed Mach, whom he considered a "genius". ${ }^{72}$ What is more, James's late "radical empiricism" is undeniably reminiscent of Mach's views. ${ }^{73}$ For this reason, Stumpf voiced his disagreement with James's doctrine friendly, but decidedly. ${ }^{74}$

Franz Brentano also undoubtedly deserves a mention in this context. Both as a man and as a thinker, Brentano had a great influence over Stumpf. Besides his intellectual debt to him, Stumpf was friends with Brentano, whom he greatly admired. Of course, his friendship with James was quite different: ${ }^{75}$ Stumpf found

71 "I read the address with extreme satisfaction. I think it is high time that someone in such an authoritative position should raise a voice against the excessively shallow dogmatism of the parallelists, who simply affirm the truth of a conception that they conceive as neat and pretty. You did the business in a perfectly masterly way. I especially admired the breadth of the treatment and the skill with which you avoided entering into any minute or secondary considerations. I can't help thinking that the day of the cruder parallelism, as the last word of scientific philosophy, is passed. That thistle needs only to be firmly grasped to show its feebleness! [...]" [31, 1896].

72 In 1882, James wrote to Alice: "Mach came to my Hotel and I spent 4 hours walking \& supping with him at his Club - an unforgettable conversation. I don't think anyone ever gave me so strong an impression of pure intellectual genius"; furthermore: "Mach, Professor of Physics, \& genius of all trades” [58, 1882]. James to Stumpf: “[. . .] Professor Mach, that truly "genialer" man" [7, 1886]. By contrast, James considered Wundt typically devoid of genius: Wundt "isn't a genius, he's a professor", he is a "Napoleon without genius" [10, 1887]; "If only he [Wundt] could show a spark of creative genius dabei!" [24, 1893]. In a letter to A. Thomsen of 1911, Mach recalls James's visit: "My personal memories of William James are very pleasant; he visited me while still in Prague in 80 or 81 . I remember no one with whom, despite the divergence of viewpoints, I could discuss so well and fruitfully. He opposed me almost everywhere and yet I benefited almost everywhere by his objections. Already at that time he avoided any drop of wine or coffee so that I believed him more of a nervous hypochondriac than a really sick man. The center of his work certainly lies in his excellent Psychology. I cannot quite come to terms with his Pragmatism. 'We cannot give up the concept of God because it promises too much'. That is a rather dangerous argument”. Quoted from E. Banks, Ernst Mach's World Elements. A Study in Natural Philosophy, Dordrecht, Springer, 2003, p. 143; German text in Ernst Mach als Aussenseiter, ed. by J.T. Blackmore and K. Hentschel, Wien, Braumüller, 1985, p. 86

73 See below in this Introduction.

74 "A growing divergence appears to be occurring in our views, dear and revered friend. [...] The positivistic theory of knowledge, in which you agree Mach, seems to me impossible, or barren" [53, 1907].

75 L. Sprung, "Brüder im Geiste. Franz Brentano und William James", in Sprung, Carl Stumpf. Eine Biographie, cit., p. 193. 
in James an allied spirit who - both in personal and in scientific matters - was tremendously distant from the scholastic style prevailing within the school of Brentano. Indeed, even though Stumpf has long been considered an orthodox follower of Brentano in philosophy, recent research has highlighted the influence exerted by Lotze. ${ }^{76}$ In fact, Stumpf eventually took his distance from both of his mentors and developed an original philosophy of his own: the correspondence testifies to the remarkable role played by William James in this evolution.

In the James-Stumpf correspondence, Brentano's name comes up twice. In 1884, Stumpf defended his teacher from a critical remark by James in Some Omissions of Introspective Psychology, where Brentano's view that introspection is infallible is ridiculed. ${ }^{77}$ Stumpf objects that while Brentano did affirm the infallibility of "internal perception", he also claimed that psychology depends on short-term memory, which is far less reliable. ${ }^{78}$ The nuanced formulation adopted for the correspondent discussion in The Principles of Psychology shows that James took note of this remark. ${ }^{79}$ Fifteen years later, in 1899, Stumpf announced to his American friend that Brentano unexpectedly supported James's theory of emotions. ${ }^{80}$ That was quite surprising to Stumpf, and is still surprising

76 Stumpf's rigorous adherence to Brentanism has been stressed by K. Schuhmann, Carl Stumpf (1848-1936), cit., p. 128. Concerning Lotze’s influence see Milkov, Carl Stumpf's Debt to Hermann Lotze, cit., and B. Centi, "Stumpf and Lotze on Space, Reality, Relation", in Carl Stumpf, From Philosophical Reflection to Interdisciplinary Scientific Investigation, ed. by S. Bonacchi and G.-J. Boudewijnse, Wien, Krammer, 2011, pp. 69-81. A balanced evaluation was given by Denis Fisette: "Some claim that Stumpf is a truly orthodox Brentanian [. . . while others [...] argue that Stumpf gradually distanced himself from Brentano's thinking and moved closer to that of Lotze. The truth must lie somewhere in the middle". D. Fisette, "Carl Stumpf", The Stanford Encyclopedia of Philosophy.

77 "As is well known, contradictory opinions about the value of introspection prevail. Comte and Maudsley, for instance, call it worthless; Ueberweg and Brentano come near calling it infallible. Both opinions are extravagancies". W. James, "On Some Omissions of Introspective Psychology", Mind 9, 1884, p. 1 [Works 13, p. 142].

78 "You do Brentano an injustice [...] if you ascribe to him such an extreme view. He emphasizes indeed that psychology is essentially dependent on observation in memory and that this is by no means infallible" [4, 1884].

79 See the footnotes to $[4,1884]$.

80 "I thought that I quite agreed with him [Brentano] regarding emotions, but then I received a 7-sheet long letter from him in which he declared himself decisively for your view and against mine" [34, 1899]. For an interpretation that links James's doctrine of emotions to intentionality (without reference to Brentano) see M. Ratcliffe, "William James on emotion and intentionality”, International Journal of Philosophical Studies 13, 2, 2005, pp. 179-202. According to Ratcliffe, it is incorrect to argue that James denied that emotions are cognitive states: rather, James remarked that bodily feelings also belong to intentionality. 
in the light of the common understanding of his doctrine. ${ }^{81}$ However, by stating that Brentano endorsed James's view on emotions, Stumpf oversimplified a much more complicated state of affairs. ${ }^{82}$ Stumpf had taken his distance from the James-Lange hypothesis in an essay of 1899, entitled Über den Begriff der Gemüthsbewegung. ${ }^{83}$ Reacting to it, Brentano criticized Stumpf's solution and rather endorsed James. ${ }^{84}$ However, in that circumstance Brentano avowed that he knew the James-Lange doctrine only "partially" and "indirectly" - and mainly from Stumpf's essay. In fact, Brentano never simply adhered to the James-Lange view of emotions: rather, he developed a position of his own and rejected Stumpf's "heterodox" stance. ${ }^{85}$

Speaking of Brentano, it might be worth making some remarks on the role of phenomenology in the correspondence. Scholars who endorse a phenomenological interpretation of James's thought ${ }^{86}$ may reasonably expect his correspondence with Stumpf to offer some support to their reading. Yet this is not necessarily the case. Needless to say, neither James nor Stumpf are best interpreted from the point of view of Husserlian phenomenology. ${ }^{87}$ By contrast, if

81 Reisenzein and Schönpflug note: "Stumpf [. . . took it to be a strength of his theory that in contrast to the theories of Wundt and James - it was in fundamental agreement with both common sense and with what he and Brentano (1874/1971) regarded as the dominant traditional line of emotion theorizing: the cognitive tradition exemplified by Aristotle, Thomas Aquinas, Descartes, and Spinoza”. R. Reisenzein, W. Schönpflug, "Stumpf's CognitiveEvaluative Theory of Emotion", American Psychologist 47, 1, 1992, p. 38.

82 "In short, Stumpf's position on this issue is prima facie a kind of compromise between James's and Brentano's views in that he argues against Brentano that sensory feeling are necessary conditions of emotional experience in general, and against James, that this phenomenal dimensional of emotional experience is not by itself a sufficient condition". D. Fisette, "Mixed Feelings. Carl Stumpf's Criticism of James and Brentano on Emotions", in Themes from Brentano, ed. by D. Fisette and G. Fréchette, Amsterdam and New York, Rodopi, 2013, p. 282.

83 C. Stumpf, "Über den Begriff der Gemüthsbewegung”, Zeitschrift für Psychologie und Physiologie der Sinnesorgane 21, 1899, pp. 47-99.

84 Brentano, Briefe an Carl Stumpf 1867-1917, p. 115 (18 August 1889).

85 See the footnotes to [34, 1899].

86 In my view, Herzog's claim that the "place of honor as a founder of phenomenological psychology [...] belongs to James" fails to provide a correct interpretative framework. M. Herzog, "William James and the Development of Phenomenological Psychology in Europe". Journal of the Human Sciences, 8, 1, 1995, pp. 29-46. See also B. Wilshire, William James and Phenomenology: A Study of "The Principles of Psychology", New York, AMS Press, 1979; J.M. Edie, William James and Phenomenology, Bloomington, Indiana University Press, 1987.

87 Husserl dedicated Logische Untersuchungen to Stumpf, who was his teacher in Halle. On the relationship between them, see D. Fisette, "A Phenomenology without Phenomena? Carl Stumpf's Critical Remarks on Husserl's Phenomenology”, Essays on Stumpf, pp. 321-358; see also R. Rollinger, Husserl's Position in the School of Brentano, Dordrecht, Kluwer, 1999. James, 
one understands "phenomenology" lato sensu and in close connexion with psychology, the term might capture a relevant feature of their thought, in line with what James calls their "sensationalistic" point of view". ${ }^{88}$ In any case, the word "phenomenology" never recurs in the James-Stumpf correspondence.

The correspondence also includes a number of discussions concerning institutional matters. At the time, psychology was going through an impressive process of institutionalization: the foundation of laboratories and journals went hand in hand with the organization of grand international conferences. ${ }^{89}$ James and Stumpf occasionally declared to be horrified by overcrowded meetings; ${ }^{90}$ yet there are exceptions. The first Congress of Psychology in Paris (1889) admittedly exerted a positive effect upon James, encouraging him in the troubled redaction of his Principles of Psychology. ${ }^{91}$ As for Stumpf, he was personally involved in the organization of the third Munich congress of 1896. Handling the congress-related correspondence exhausted him; ${ }^{92}$ however, he defended the organization against Balwin's criticism. ${ }^{93}$ Besides, in their letters the two friends occasionally linger on their (mostly unsuccessful) attempts at translating James's works into German, or Stumpf's into English. ${ }^{94}$ In 1893, James asked Stumpf to join the editorial board of the Psychological Review. ${ }^{95}$ Later, Stumpf successfully nominated James for the prestigious Akademie der Wissenschaften of Berlin. ${ }^{96}$ James's curiosity as to the number and the names of

who had no personal acquaintance with Husserl, gave negative advice as to a translation into English of Logische Untersuchungen. See H. Spiegelberg, The Phenomenological Movement. A Historical Introduction, Den Haag, Nijhoff, 1960, pp. 112-113.

88 See below, sect. 2 of this Introduction. As to Stumpf's relatively narrow definition of phenomenology, see R. Rollinger, "Stumpf on Phenomena and Phenomenology", Austrian Phenomenology: Brentano, Husserl, and Meinong on Mind and Object. Frankfurt a. M., Ontos, 2008, pp. 139-156.

89 M. Savourin, S. Cooper, "The first International Congress of Physiological Psychology (Paris, August 1889): The birth of the International Union of Psychological Science”, International Journal of Psychology 49, 2014, pp. 222-232. See also H. Piéron, "Histoire succincte des Congrès internationaux de Psychologie”, L'année psychologique 54, 1954, pp. 397-405.

90 [15, 1891], [16, 1891].

91 [12, 1899]. The Congrès international de psychologie took place in Paris, 6-10 August 1889. 92 Stumpf complains: "I had unending correspondence with foreign scholars and with the general secretary" [30, 1896].

93 J.M. Baldwin, "The Third Congress of Psychology", The Nation. A Weekly Journal Devoted to Politics, Literature, Science and Art 63, No 1628, 1896, pp. 192-193. See [30, 1896] and the relative footnotes for further reference.

94 [15, 1891], [16, 1891], [18, 1891], [29, 1895], [30, 1896], [31, 1896].

$95[25,1893]$.

$96[38,1899]$. 
the scientists appointed together with him reveal that he attached a degree of importance to this invitation. ${ }^{97}$ He did not attend the ceremony though. ${ }^{98}$

Personal matters like travels, family, and health also find their way in the correspondence. As already pointed out, a second meeting took place in Munich in 1893. The outcome of this long-awaited event was disappointing for Stumpf. In a letter of 17 May 1893, he complains that in the course of a whole year spent in Europe together with his family, James devoted to him only a couple of hurried hours. ${ }^{99}$ He also regrets to have missed the chance of meeting James's wife. ${ }^{100}$ James's reassuring words deserve a long quotation:

Your letter of the 17th., just received, touches me very much, and confirms me in my habitual belief that your heart is as strong and active an organ as your head. But how could I have conveyed to you the impression that my feeling of personal affection for you, and satisfaction in being able to count you as a friend, had grown less in the past ten years? Older I am indeed, and probably much duller, but I speak sincerely when I say that during my last visit I felt more intimately and closely the charm of your character and our intellectual kinship than when we were together ten years ago in Prag. ${ }^{101}$

The correspondence tells of subsequent unsuccessful attempts to arrange a meeting. James missed the 1896 Munich congress organized by Stumpf. ${ }^{102}$ In 1899, James sailed again to Germany to recover at Nauheim's medical baths. Rather depressed, he did not feel like meeting people; when he finally wrote to Stumpf, it was too late to arrange a visit. ${ }^{103}$

$97[42,1900]$.

$98[40,1900]$.

99 "You are in Europe for a full year - a year that I have been looking forward to for 10 years - and of this year, few hours were allotted to seeing each other again, hours in which your thoughts and feelings were still occupied by urgent matters! I cannot reproach you for this, of course, but I am sad about it; so sad, that - to say it openly - I have the uncertain feeling that your friendship has lost some of its liveliness through the years, that you perhaps have not found in it what you promised yourself initially, or that something about me has proven alien or unpleasant to you" [23, 1893].

100 "I am infinitely sorry that we did not see your dear wife more at all, and that $I$ did not get acquainted with her at all! My wife and sister-in-law were so delighted by her that I have to view it as a great loss" [23, 1893].

101 [24, 1893].

102 "I ruined myself financially by my last excursion en famille to Europe, and nothing but the need of foreign travel for my health could justify so speedy a repetition of the process. Moreover, it unsettles my americanism (that tender plant) to go too often abroad, and that must be weighed against the intellectual and social advantages of the Congress" [29, 1895]. 103 [33, 1899]. 
The correspondents also touch upon family matters. New births and, sadly, the loss of James's child in $1885^{104}$ are registered in the course of the years. During his sabbatical in 1882, James had left Alice with their second child of three months. ${ }^{105}$ At the time, Stumpf introduced him to his wife Hermine - "a nice little German professor's wife, with many ach Gotts \& Herrjeses'es” - and the "little Rudolf or Rudi, 14 months old, with a sharp aquiline nose like his father's and a large white forehead on which one might draw the plan of the city". ${ }^{106}$ An irresistibly amusing touch is added by an episode occurred to the Jameses during their stay in Florence in 1893: "If you could have seen the confusion in which my last six weeks have been spent [...], you would excuse any derelictions on my part. Incessant sociability in florence, pushed to such an extreme that one pair of young American friends came and had a baby (!!!) in our appartment, there being no other convenient place for the event to take place in". ${ }^{107}$ Finally, the letters occasionally touch upon politics, the main topic being the Dreyfus affair. ${ }^{108}$ Both friends were shocked by the attempt to condemn an innocent; even their sympathy for France and the French yielded as a consequence. James's letters also interestingly reflect his anti-imperialism. ${ }^{109}$

$104[7,1886]$.

105 Alice and William James had five children: Henry (1879-1947), William (1882-1961), Herman (1884-1885), Margaret Mary (1887-1950) and Alexander Robertson (1890-1946).

106 Quoting from James's letter to his wife Alice [58, 1882]. Hermine and Carl Stumpf had three children: Rudolf (1881-1945), Felix (1885-1970), and Elisabeth (1891-1976).

107 [22, 1893].

108 [33, 1899], [34, 1899], [35, 1899]. See D. Weinfeld, "Les Intellectuels in America: William James, the Dreyfus Affair, and the Development of the Pragmatist Intellectual”, The Journal of American History, 2018, pp. 19-44.

109 [45, 1900], [47, 1901]. See A. Livingstone, Damn Great Empires! William James and the Politics of Pragmatism, Oxford, Oxford University Press, 2016. 